\title{
Orbital control on the timing of oceanic anoxia in the Late Cretaceous
}

\author{
Sietske J. Batenburg ${ }^{1,2,{ }^{*}}$, David De Vleeschouwer ${ }^{3,4,{ }^{*}}$, Mario Sprovieri ${ }^{5}$, Frederik J. Hilgen ${ }^{6}$, Andrew S. Gale ${ }^{7}$, \\ Brad S. Singer ${ }^{8}$, Christian Koeberl ${ }^{9,10}$, Rodolfo Coccioni ${ }^{11}$, Philippe Claeys ${ }^{4}$, and Alessandro Montanari ${ }^{12}$ \\ ${ }^{1}$ Department of Earth Sciences, University of Oxford, Oxford, UK \\ ${ }^{2}$ Institut für Geowissenschaften, Goethe-Universität Frankfurt, Frankfurt am Main, Germany \\ ${ }^{3}$ MARUM, Universität Bremen, Bremen, Germany \\ ${ }^{4}$ Earth System Sciences, Vrije Universiteit Brussel, Brussels, Belgium \\ ${ }^{5}$ IAMC-CNR Capo Granitola, Campobello di Mazara, Italy \\ ${ }^{6}$ Department of Earth Sciences, Utrecht University, Utrecht, the Netherlands \\ ${ }^{7}$ School of Earth and Environmental Sciences, University of Portsmouth, Portsmouth, UK \\ ${ }^{8}$ Department of Geoscience, University of Wisconsin-Madison, Madison, Wisconsin, USA \\ ${ }^{9}$ Department of Lithospheric Research, University of Vienna, Vienna, Austria \\ ${ }^{10}$ Natural History Museum Vienna, Vienna, Austria \\ ${ }^{11}$ Dipartimento di Scienze della Terra, della Vita e dell'Ambiente, Università degli Studi “Carlo Bo", Urbino, Italy \\ ${ }^{12}$ Osservatorio Geologico di Coldigioco, 62020 Frontale di Apiro, Italy \\ *These authors contributed equally to this work.
}

Correspondence to: Sietske J. Batenburg (sbatenburg@ gmail.com)

Received: 4 December 2015 - Published in Clim. Past Discuss.: 26 January 2016

Revised: 2 August 2016 - Accepted: 26 August 2016 - Published: 19 October 2016

\begin{abstract}
The oceans at the time of the CenomanianTuronian transition were abruptly perturbed by a period of bottom-water anoxia. This led to the brief but widespread deposition of black organic-rich shales, such as the Livello Bonarelli in the Umbria-Marche Basin (Italy). Despite intensive studies, the origin and exact timing of this event are still debated. In this study, we assess leading hypotheses about the inception of oceanic anoxia in the Late Cretaceous greenhouse world by providing a $6 \mathrm{Myr}$ long astronomically tuned timescale across the Cenomanian-Turonian boundary. We procure insights into the relationship between orbital forcing and the Late Cretaceous carbon cycle by deciphering the imprint of astronomical cycles on lithologic, physical properties, and stable isotope records, obtained from the Bottaccione, Contessa and Furlo sections in the Umbria-Marche Basin. The deposition of black shales and cherts, as well as the onset of oceanic anoxia, is related to maxima in the $405 \mathrm{kyr}$ cycle of eccentricity-modulated precession. Correlation to radioisotopic ages from the Western Interior (USA) provides unprecedented age control for the studied Italian
\end{abstract}

successions. The most likely tuned age for the base of the Livello Bonarelli is $94.17 \pm 0.15 \mathrm{Ma}$ (tuning 1); however, a $405 \mathrm{kyr}$ older age cannot be excluded (tuning 2) due to uncertainties in stratigraphic correlation, radioisotopic dating, and orbital configuration. Our cyclostratigraphic framework suggests that the exact timing of major carbon cycle perturbations during the Cretaceous may be linked to increased variability in seasonality (i.e. a $405 \mathrm{kyr}$ eccentricity maximum) after the prolonged avoidance of seasonal extremes (i.e. a $2.4 \mathrm{Myr}$ eccentricity minimum). Volcanism is probably the ultimate driver of oceanic anoxia, but orbital periodicities determine the exact timing of carbon cycle perturbations in the Late Cretaceous. This unites two leading hypotheses about the inception of oceanic anoxia in the Late Cretaceous greenhouse world.

\section{Introduction}

The organic-rich Livello Bonarelli formed as a result of oxygen deficiency and carbonate dissolution in the oceans during 
the Cenomanian-Turonian $(\mathrm{C} / \mathrm{T})$ transition. During Oceanic Anoxic Event 2 (OAE 2), a combination of factors caused increased productivity, incomplete decomposition of organic matter and widespread deposition of black shales. Although these sediments have been intensively studied, the exact extent, cause, timing and duration of oceanic anoxia are debated (Sinton and Duncan, 1997; Mitchell et al., 2008). Contrasting causal mechanisms have been suggested, including stratification of the water column (Lanci et al., 2010) versus intensification of the hydrological cycle driving a dynamic ocean circulation (Trabucho-Alexandre et al., 2010). Studies on trace-element and (radiogenic) isotope compositions of Cenomanian marine successions have suggested a volcanic origin of OAE 2, with large-scale volcanism delivering nutrients to the semi-enclosed proto-North Atlantic (Du Vivier et al., 2014; Zheng et al., 2013; and references therein). Deciphering the importance of volcanic and oceanographic processes requires tight constraints on their relative timing. Regularly occurring black cherts and shales below the Livello Bonarelli demonstrate that oceanic conditions in the Umbria-Marche Basin were punctuated by episodes of regional anoxia from the mid-Cenomanian onwards. Their hierarchical stacking pattern suggests an orbital control on the deposition of organic-rich horizons (Mitchell et al., 2008; Lanci et al., 2010). Stable carbon isotope data reveal that long-term variations in eccentricity paced the carbon cycle (Sprovieri et al., 2013) and sea level changes (Voigt et al., 2006) of the Late Cretaceous. Here we investigate the role of orbital forcing on climate and the carbon cycle and, specifically, on organic-rich sedimentation prior to, during, and after OAE 2.

We also explore the potential for establishing an anchored astrochronology for the $\mathrm{C} / \mathrm{T}$ interval in Europe. Recent improvements in the astronomical solution La2011 (Laskar et al., 2011b) and in the intercalibration of radiometric and astronomical dating techniques (Kuiper et al., 2008; Renne et al., 2013) allow the extension of the astronomical timescale into the Cretaceous. The $\mathrm{C} / \mathrm{T}$ boundary in the Western Interior (USA) has been dated at 93.90 $\pm 0.15 \mathrm{Ma}$ by intercalibration of radioisotopic and astrochronologic timescales (Meyers et al., 2012b). Also, reinterpretation of proxy records spanning the $\mathrm{C} / \mathrm{T}$ interval seems to resolve discrepancies in reported durations of the OAE 2 (Meyers et al., 2012a; Sageman et al., 2006). The well-documented Italian rhythmic successions, reference sections for climatic processes in the Tethyan realm, need to be tied in with the numerical timescale. Biostratigraphic correlation to radioisotopically dated ash beds in the Western Interior is complicated by the provinciality of faunas and floras. However, $\delta^{13} \mathrm{C}$ stratigraphy provides a reliable correlation tool (Jenkyns et al., 1994) and we present a new ${ }^{40} \mathrm{Ar} /{ }^{39} \mathrm{Ar}$ age for the Thatcher bentonite from the Western Interior occurring within the mid-Cenomanian $\delta^{13} \mathrm{C}$ event (MCE). This study integrates the well-developed cyclostratigraphy from the Umbria-Marche Basin with radioisotopic ages from the
Western Interior and derives a numerical timescale for this critical interval in Earth's history.

\section{Materials and methods}

\subsection{Geological setting and proxy records}

Previous studies have investigated the rhythmic nature of the bedded limestones, (black) cherts and shales in sections near Gubbio (de Boer, 1982, 1983; Herbert and Fischer, 1986; Schwarzacher, 1994; Sprovieri et al., 2013) and at Furlo (Beaudouin et al., 1996; Mitchell et al., 2008; Lanci et al., 2010). In this study, we present new geophysical and stable isotope data generated from the Cenomanian interval at the Furlo quarry, and from uppermost Cenomanian and Turonian deposits in the Gola del Bottaccione (Fig. 1). In addition, stable carbon and oxygen isotope data from the Turonian of the Contessa quarry, published by Stoll and Schrag (2000), are used. The proxy records from the Bottaccione, Contessa and Furlo sections are all presented on the same height scale, using the recent height scale for the Cretaceous UmbriaMarche Basin, introduced by Sprovieri et al. (2013).

In the Umbria-Marche Basin, the Livello Bonarelli separates the Cenomanian white limestones of the Scaglia Bianca from the Turonian pink limestones of the Scaglia Rossa. The strong changes in sedimentary facies necessitate the application of different proxy methods as archives of palaeoclimatic variability. Colour reflectance was measured in the Cenomanian Scaglia Bianca to capture the alternation of black cherts and shales with white limestones and light-grey cherts. For the Turonian Scaglia Rossa, where colour variations are limited, magnetic susceptibility measurements reveal variations in the detrital contribution, as clastic particles are generally richer in ferromagnetic minerals. To investigate the Livello Bonarelli in high-resolution, X-ray fluorescence (XRF) data were generated, reflecting variations in detrital contribution $\left(\mathrm{SiO}_{2}, \mathrm{Al}_{2} \mathrm{O}_{3}, \mathrm{TiO}_{2}\right)$ and organic matter content (loss on ignition, LOI). High $\mathrm{Al}_{2} \mathrm{O}_{3}$ likely indicates a strong riverine input, in contrast to $\mathrm{TiO}_{2}$, reflecting a stronger dust contribution. The $\mathrm{SiO}_{2}$ can be both detrital and biogenic in origin. The LOI data reflect the weight of volatile substances lost upon heating and give a measure of the organic content.

The W4 member of the Scaglia Bianca formation at Furlo (Coccioni, 1996) consists mainly of light-grey to white pelagic biomicrite alternating with light-grey nodular to bedded cherts and tabular black cherts (Mitchell et al., 2008). The section was logged in detail and sampled at $3 \mathrm{~cm}$ spacing with an electric handheld drill. The total light reflectance $\left(L^{*}\right.$, in \%) was measured with a Konica Minolta CM 2002 spectrophotometer on the surface of rock powders, recording the reflected energy (RSC) at 400 to $700 \mathrm{~nm}$ wavelengths in $10 \mathrm{~nm}$ steps (averaged over three measurements). For the Furlo section, $\delta^{18} \mathrm{O}$ and $\delta^{13} \mathrm{C}$ were measured with a GasBench II device and a Thermo Electron Delta Plus XP mass spectrometer at the IAMC-CNR in Naples. Stable isotope 


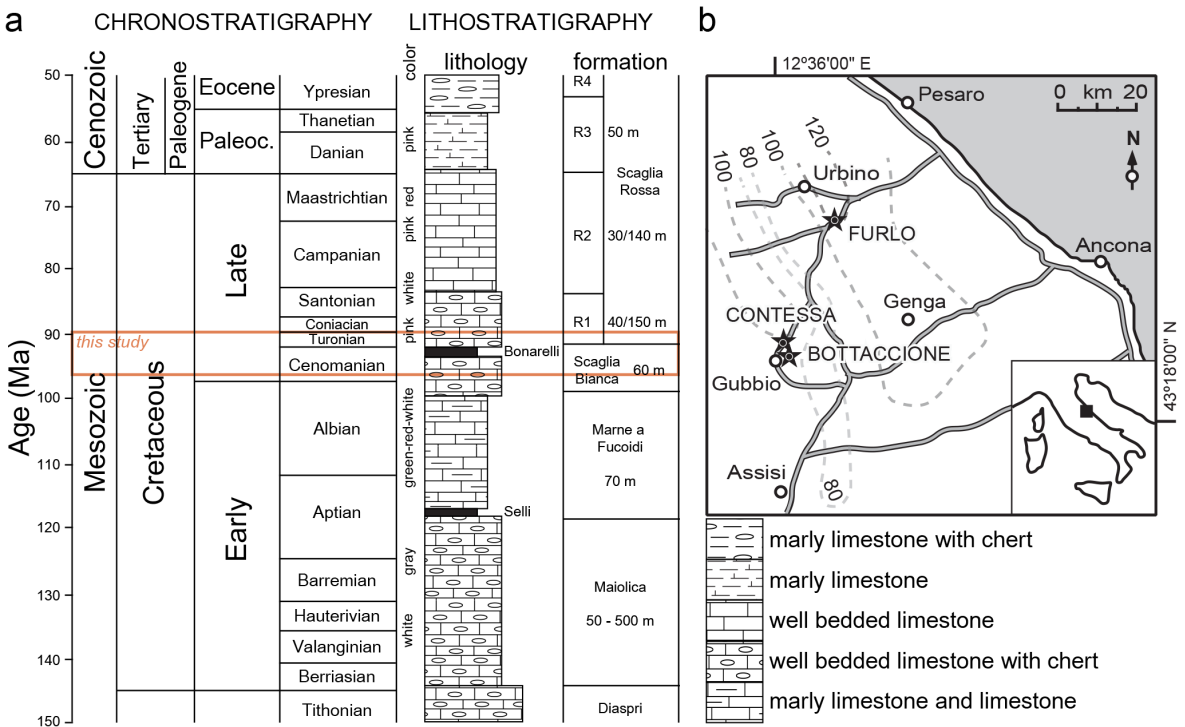

Figure 1. (a) Chrono- and lithostratigraphy of the Umbria-Marche succession in the Apennine mountains (adapted from Alvarez et al., 2011). (b) Geographic setting of the study sections with isopachs of the Bonarelli level (in cm) from Montanari et al. (1989).

ratios were measured on powders of all lithologies, and repeated with larger sample amounts when carbonate contents were insufficient.

The overlying Livello Bonarelli consists of alternating 5$50 \mathrm{~mm}$ layers of organic-rich black shale (up to $26 \%$ TOC) and lighter radiolarite (Kuroda et al., 2007). The Bonarelli interval was sampled at a $2 \mathrm{~cm}$ resolution at both the Furlo and Bottaccione sections. Contents of major and selected minor elements from the Livello Bonarelli were determined with a Philips PW2400 sequential XRF spectrometer equipped with a Rh-excitation source at the University of Vienna. Details of the analytical procedures and accuracies are similar to those given in Reimold et al. (1994).

The overlying Turonian R1 member of the Scaglia Rossa formation consists of pink pelagic limestones and marly limestones with nodular to laminar red to grey cherts (Montanari et al., 1989). The $38 \mathrm{~m}$ above the Livello Bonarelli at the Bottaccione section was logged in detail and the section was sampled at $5 \mathrm{~cm}$ spacing from 10 to $30 \mathrm{~m}$ above the Livello Bonarelli. Magnetic susceptibility (MS) was measured with a Bartington MS2B dual-frequency magnetometer at the Osservatorio Geologico de Coldigioco (averaged over three measurements). Stable isotope ratios were measured with a Kiel III device coupled to a Thermo Finnigan delta + XL mass spectrometer at the Vrije Universiteit Brussel.

\section{2 $\mathrm{Ar} / \mathrm{Ar}$ dating}

A new ${ }^{40} \mathrm{Ar} /{ }^{39} \mathrm{Ar}$ age was obtained for the mid-Cenomanian event in the $\delta^{13} \mathrm{C}$ record. Sample $91-0-03$ is the same material used by Obradovich (1993); it is from an ash bed in the Conlinoceros gilberti ammonite zone in the Western Interior (USA), commonly known as the Thatcher bentonite.
Laser fusion ${ }^{40} \mathrm{Ar} /{ }^{39} \mathrm{Ar}$ analyses of single sanidine crystals were performed at the WiscAr laboratory, University of Wisconsin-Madison, following methods detailed in Sageman et al. (2014). A total of 53 crystals were dated. Eleven crystals that yielded less than $98.5 \%$ radiogenic ${ }^{40} \mathrm{Ar}$ were excluded from the mean, as was one inherited crystal that gave an apparent age greater than $101 \mathrm{Ma}$. Ages are calculated relative to $28.201 \pm 0.046 \mathrm{Ma}$ Fish Canyon sanidines (Kuiper et al., 2008) using the ${ }^{40} \mathrm{~K}$ decay constants of Min et al. (2000).

\subsection{Time series analysis}

Time series analysis was carried out using the multitaper method (MTM) (Thomson, 1982) with LOWSPEC background estimation (Meyers, 2012), as implemented in the R package "astrochron" (Meyers, 2014). We used three $2 \pi$ prolate tapers and confidence levels were calculated with the LOWESS-based (Cleveland, 1979) procedure of Ruckstuhl et al. (2001). The continuous wavelet transform is used to decompose the one-dimensional time series into their twodimensional time-frequency representations. Band-pass filters are applied with Analyseries (Paillard et al., 1996). Sedimentation rates within the Scaglia Rossa and Scaglia Bianca formations are estimated with the evolutionary average spectral misfit (E-ASM) method (Meyers and Sageman, 2007), using all frequencies for which the MTM harmonic $F$ test reports a line component that exceeds $80 \%$ probability. For the Bonarelli level, sedimentation rate is estimated with the standard ASM method. Predicted orbital periods for the late Cretaceous (93 Ma) are from Berger et al. (1992). 


\section{Results}

\subsection{Lithology and proxy data}

The Cenomanian black shales and cherts in the Furlo section display a hierarchical stacking pattern, with groups of two to four organic-rich levels, spaced $\sim 20 \mathrm{~cm}$ apart (Figs. 2 and $3)$. Black cherts and shales increase in number up-section, although they are lacking in the interval between 483 and $485 \mathrm{~m}$. Between $483.5 \mathrm{~m}$ and the Livello Bonarelli, the spacing between beds increases. Despite this increase, the two thick cherts directly underlying the Livello Bonarelli display a similar grouping to the cherts throughout the section. The total reflectance record $\left(L^{*}\right.$, in \%) captures this stacking pattern: grey and black cherts reflect little light and display shifts towards lower $L^{*}$ values, in contrast to the bright micritic Scaglia Bianca limestones with high $L^{*}$ values. Increased variability and negative values of $\delta^{13} \mathrm{C}$ and $\delta^{18} \mathrm{O}$ coincide with higher variability in reflectance and with the occurrence of organic-rich layers.

XRF data from the Livello Bonarelli at Furlo display a marked variability at a $12 \mathrm{~cm}$ scale (Fig. 4). The $\mathrm{TiO}_{2}$ and $\mathrm{Al}_{2} \mathrm{O}_{3}$ records display very similar behaviour, whereas $\mathrm{SiO}_{2}$ and LOI data additionally show variation on a $40 \mathrm{~cm}$ scale. At Bottaccione, a marked variability can be observed at an $8 \mathrm{~cm}$ scale in the $\mathrm{SiO}_{2}, \mathrm{TiO}_{2}$ and $\mathrm{Al}_{2} \mathrm{O}_{3}$ data from the Livello Bonarelli (Fig. 5).

The Scaglia Rossa pelagic limestones were studied in the classic Contessa and Bottaccione sections near Gubbio. Oscillations between radiolarian cherts and foram-coccolith pelagic limestones show hierarchical bundles of two to five chert layers per bundle. These bundles could be correlated amongst the Contessa and Bottaccione sections and are indicated by brackets in Fig. 3. The lithologic log shown in Fig. 3 is for the Bottaccione section. The magnetic susceptibility signal of the Bottaccione section accentuates the hierarchical stacking pattern, showing an increased magnetic susceptibility signal in intervals characterized by frequent chert beds (Fig. 3).

\section{$3.2 \mathrm{Ar} / \mathrm{Ar}$}

The inverse variance weighted mean age of 41 of the 53 sanidine crystals measured from sample 91-0-03 gives an age of $96.21 \pm 0.16 / 0.36 \mathrm{Ma}$ ( $2 \sigma$ analytical uncertainty/full uncertainty including decay constant and standard age), with a mean square of weighted deviates (MSDW) of 0.69 (Fig. 6). The complete set of analytical and standard data is in Supplement Table 1.

\subsection{Time series analysis}

Spectral analyses by MTM/LOWSPEC, in combination with the evolutionary average spectral misfit (E-ASM; Meyers and Sageman, 2007) method, suggest an average sedimentation rate around $11 \mathrm{~m} \mathrm{Myr}^{-1}$ throughout the studied interval, excluding the Livello Bonarelli (Figs. 7 and 8).

In the Cenomanian interval, the MTM/LOWSPEC spectra of all proxies exhibit a spectral peak exceeding the $95 \%$ confidence level for a cycle thickness of $0.25 \mathrm{~m}$, corresponding to the spacing between individual chert layers, which is interpreted as the imprint of $\sim 21 \mathrm{kyr}$ precession (left column in Fig. 7). The average accumulation rate is $11 \mathrm{~m} \mathrm{Myr}^{-1}$ (lower panel in Fig. 8) and the dominant periodicities at 1 and $4 \mathrm{~m}$ correspond to $\sim 100$ and $405 \mathrm{kyr}$ eccentricity, respectively (Fig. 7).

Similarly, in the Turonian interval, a $0.25 \mathrm{~m}$ spectral peak exceeds the $95 \%$ confidence level for all proxies and is interpreted as the imprint of precession (right column in Fig. 7). Here, the eccentricity components are represented by dominant periodicities of 4.66 and $1.16 \mathrm{~m}$ and the average accumulation rate is $10.5 \mathrm{~m} \mathrm{Myr}^{-1}$ (upper panel in Fig. 8).

We also find a statistically significant imprint of obliquity in Furlo's Cenomanian $\delta^{13} \mathrm{C}$ record which confirms an important obliquity control on the greenhouse carbon cycle, as suggested by Laurin et al. (2015). Grouping of precessionrelated chert-limestone alternations in $\sim 100 \mathrm{kyr}$ bundles is indicated by brackets next to the lithological log in Fig. 3, and 405 kyr eccentricity cycles are denoted by yellow-white alternating bands. The definition of eccentricity minima and maxima is based on the extremes of the 3-5 m band-pass filter of $L^{*}$ (Furlo) and MS (Bottaccione), as well as on the stacking pattern of shales and cherts (Bottaccione).

For the Livello Bonarelli from Furlo $(124 \mathrm{~cm})$, a duration estimate is obtained from $2 \mathrm{~cm}$ spaced XRF spectrometry data. The MTM spectral analyses of $\mathrm{SiO}_{2}$ yield dominant periodicities of $\sim 40, \sim 12$, and $\sim 6 \mathrm{~cm}$ (Fig. 3a). We calculate the ASM using the results of MTM harmonic analysis $(>80 \%)$, and obtain an optimal sedimentation rate of $0.286 \mathrm{~cm} \mathrm{kyr}^{-1}$ for the Bonarelli in Furlo. Hence, we interpret the reported periodicities as the imprint of short eccentricity, obliquity, and precession and estimate the duration of the Livello Bonarelli at $413 \mathrm{kyr}$.

ASM analysis of the $\mathrm{Al}_{2} \mathrm{O}_{3}$ data from the $82 \mathrm{~cm}$ thick Livello Bonarelli at Bottaccione suggests an optimal sedimentation rate of $0.208 \mathrm{~cm} \mathrm{kyr}^{-1}$ (Fig. 5). The $\sim 8 \mathrm{~cm}$ thick cycles are interpreted as the imprint of obliquity, and the duration of Livello Bonarelli at Bottaccione is estimated at $410 \mathrm{kyr}$, comparable to the estimate of $413 \mathrm{kyr}$ at Furlo.

\section{Discussion}

\subsection{Proxy records and correlation of the $\mathrm{C} / \mathrm{T}$ boundary}

The records of $\delta^{18} \mathrm{O}$ and $\delta^{13} \mathrm{C}$ show long-term trends over the successions, although the $\delta^{18} \mathrm{O}$ record in particular displays scatter, which might be due to an influence of diagenesis. The $\delta^{13} \mathrm{C}$ signal is generally more robust to post-depositional alteration (Jenkyns et al., 1994), and bulk carbonate $\delta^{13} \mathrm{C}$ patterns constitute a powerful tool for stratigraphic correlation, 


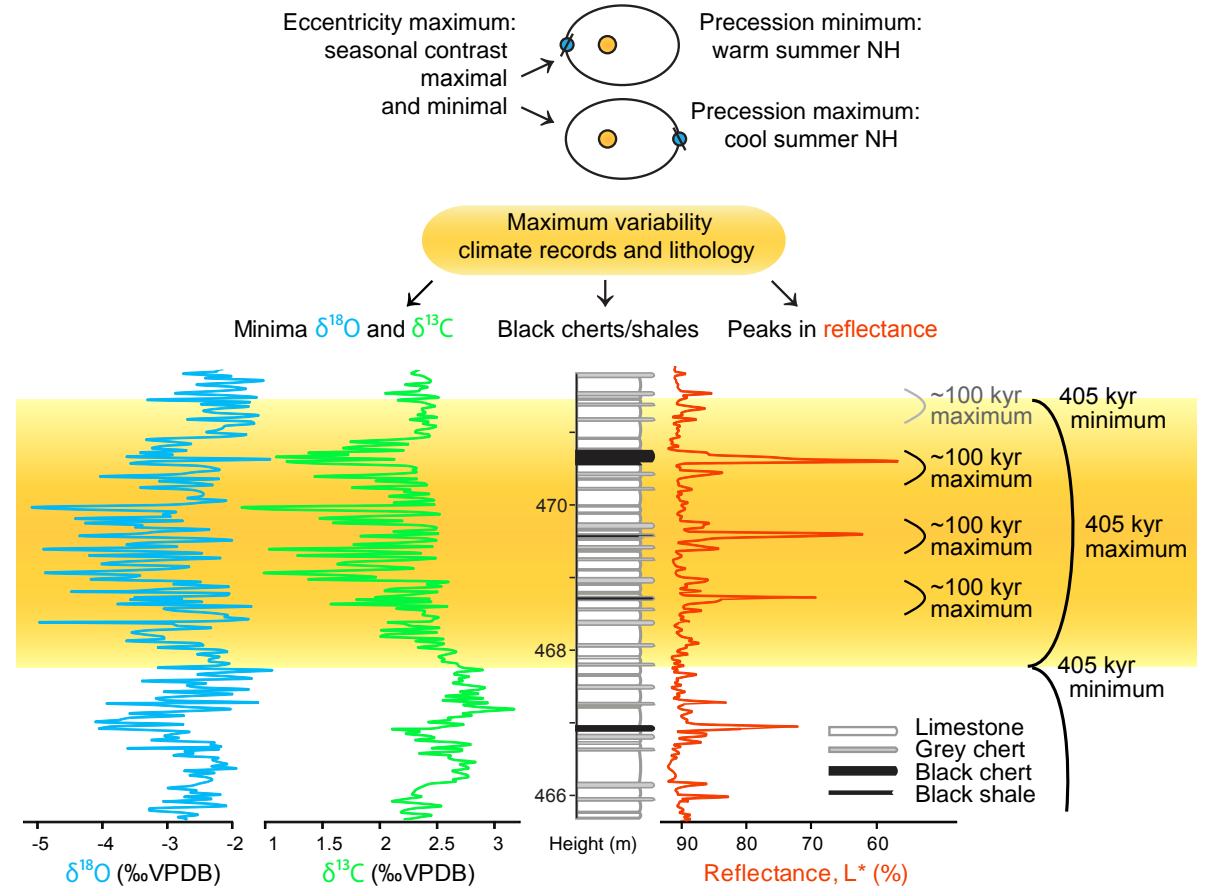

Figure 2. Phase relationship between eccentricity and proxy records. During eccentricity maxima, the seasonal contrast for the NH is maximally enhanced during precession minima and maximally reduced during precession maxima (top: schematic representation of the Earth's orbit around the Sun). Hence, climate variability is strongly amplified during eccentricity maxima, triggering the highest variability in the climate-sensitive records and hierarchical organization of chert-limestone alternations.

Table 1. Astronomical tuning options for biostratigraphic and isotopic events and comparison to radioisotopic ages. Uncertainties on tuned absolute ages comprise the uncertainty in the stratigraphic position and/or correlation of an event $( \pm 0.75 \mathrm{~m})$ and the uncertainty in the astronomical target curve (Laskar et al., 2011a) $( \pm 0.079 \mathrm{Myr})$. The numerical age of the $\mathrm{C} / \mathrm{T}$ boundary is based on intercalibration of ${ }^{40} \mathrm{Ar} /{ }^{39} \mathrm{Ar}$ dating, U-Pb dating and astrochronology (Meyers et al., 2012b). The radioisotopic age of the base of Whiteinella archaeocretacea is the weighted mean age of single- and multicrystal ${ }^{40} \mathrm{Ar} /{ }^{39} \mathrm{Ar}$ ages of bentonite A. Radioisotopic ages for the first peak of the mid-Cenomanian event come from single-crystal ${ }^{40} \mathrm{Ar} /{ }^{39} \mathrm{Ar}$ dating of the Thatcher bentonite in the Conlinceras tarrantense zone (Calycoceras gilberti). All radioisotopic ages are reported in $2 \sigma$ and using an Fish Canyon sanidine age of $28.201 \pm 0.046 \mathrm{ka}(1 \sigma)$ (Kuiper et al., 2008). Event names in italics refer to nomenclature of Jarvis et al. (2006).

\begin{tabular}{|c|c|c|c|c|}
\hline Event & $\begin{array}{l}\text { Stratigraphic } \\
\text { level }(\mathrm{m})\end{array}$ & $\begin{array}{l}\text { Tuning } 1 \\
\text { (Ma) with } \\
\text { stratigraphic } \\
\text { and astronomical } \\
\text { uncertainty }\end{array}$ & $\begin{array}{l}\text { Tuning } 2 \\
\text { (Ma) with } \\
\text { stratigraphic } \\
\text { and astronomical } \\
\text { uncertainty }\end{array}$ & $\begin{array}{l}\text { Radioisotopic dating } \\
\text { (Ma) with } 2 \sigma \text { radiometric } \\
\text { uncertainty }\end{array}$ \\
\hline Hitch Wood $\delta^{13} \mathrm{C}$ excursion & $516.24 \mathrm{~m}$ & $90.59 \pm 0.15$ & $90.99 \pm 0.15$ & \\
\hline Base $D$. primitiva $-M$. sigali & $91.31 \pm 0.15$ & $91.72 \pm 0.15$ & & \\
\hline Round Down $\delta^{13} \mathrm{C}$ excursion & $499.44 \mathrm{~m}$ & $92.32 \pm 0.15$ & $92.72 \pm 0.15$ & \\
\hline Base NC14 & $493.85 \mathrm{~m}$ & $92.93 \pm 0.15$ & $93.33 \pm 0.15$ & \\
\hline Base Helvetoglobotruncana helvetica & $491.85 \mathrm{~m}$ & $93.17 \pm 0.15$ & $93.57 \pm 0.15$ & \\
\hline $\mathrm{C} / \mathrm{T}$ boundary & $487.47 \mathrm{~m}$ & $93.69 \pm 0.15$ & $94.10 \pm 0.15$ & $\begin{array}{l}93.90 \pm 0.15 \\
\text { Meyers et al. (2012b) }\end{array}$ \\
\hline Base Whiteinella archaeocretacea & $485.70 \mathrm{~m}$ & $94.17 \pm 0.15$ & $94.57 \pm 0.15$ & $\begin{array}{l}94.20 \pm 0.28 \\
\text { Meyers et al. }(2012 b)\end{array}$ \\
\hline Base NC12 & $484.20 \mathrm{~m}$ & $94.28 \pm 0.15$ & $94.68 \pm 0.15$ & \\
\hline Base CC10 & $482.77 \mathrm{~m}$ & $94.39 \pm 0.15$ & $94.79 \pm 0.15$ & \\
\hline First peak mid-Cenomanian event & $466.47 \mathrm{~m}$ & $96.09 \pm 0.15$ & $96.49 \pm 0.15$ & $96.21 \pm 0.36$ (this study) \\
\hline
\end{tabular}




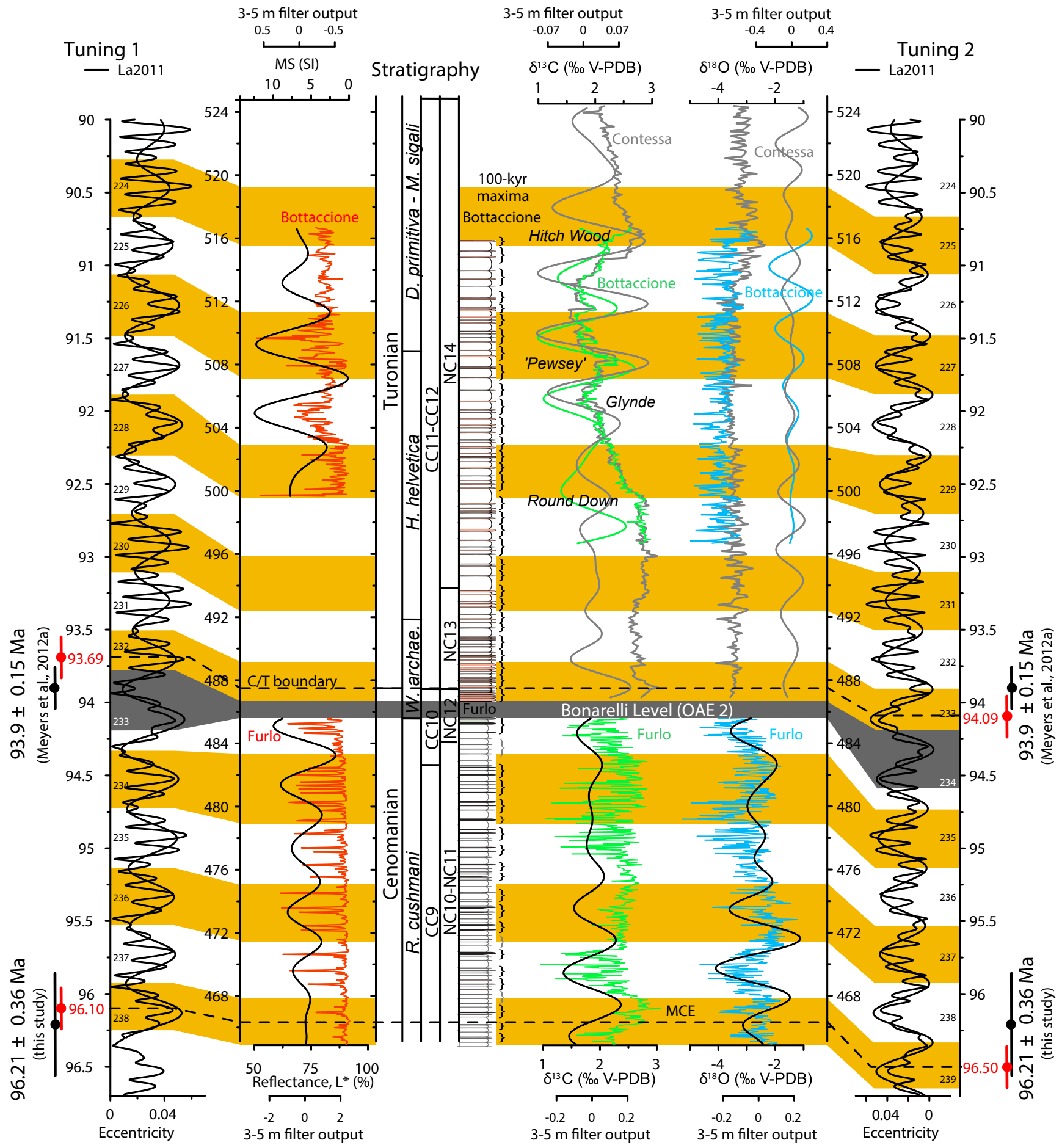

Figure 3. Cyclostratigraphic interpretation of the C/T interval of the Umbria-Marche Basin. Brackets indicate $100 \mathrm{kyr}$ bundles of precessionpaced lithological alternations, further grouping in $405 \mathrm{kyr}$ cycles is indicated by alternating yellow-white bands. Geophysical records $\left(L^{*}\right.$ and MS) accentuate the hierarchical stacking pattern. Stable isotope ratios show increased amplitude and a tendency towards more negative values during eccentricity maxima. Isotopic records in grey are from Stoll and Schrag (2000). Event names in italics refer to nomenclature of Jarvis et al. (2006). Astronomical tuning options to La2011 are presented, with $405 \mathrm{kyr}$ cycle numbering back from the present day, next to radioisotopic ages discussed in this study. 

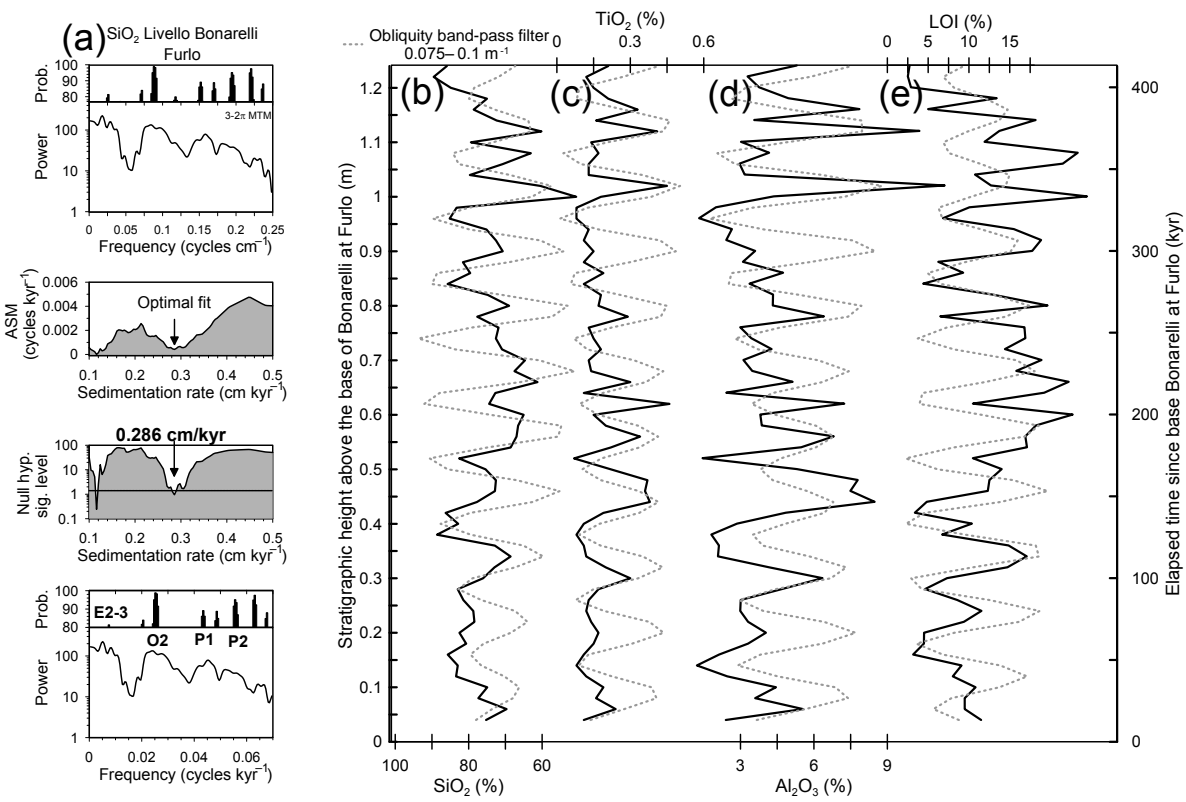

Figure 4. Duration estimate of Livello Bonarelli at Furlo based on (a) the average spectral misfit (ASM) method. (b-e) $\mathrm{SiO}_{2}$, $\mathrm{TiO}_{2}$, and $\mathrm{Al}_{2} \mathrm{O}_{3}$ contents and loss-on-ignition (LOI) data show $\sim 12 \mathrm{~cm}$ thick cycles, interpreted as obliquity. The duration of Livello Bonarelli at Furlo is estimated at $413 \mathrm{kyr}$.
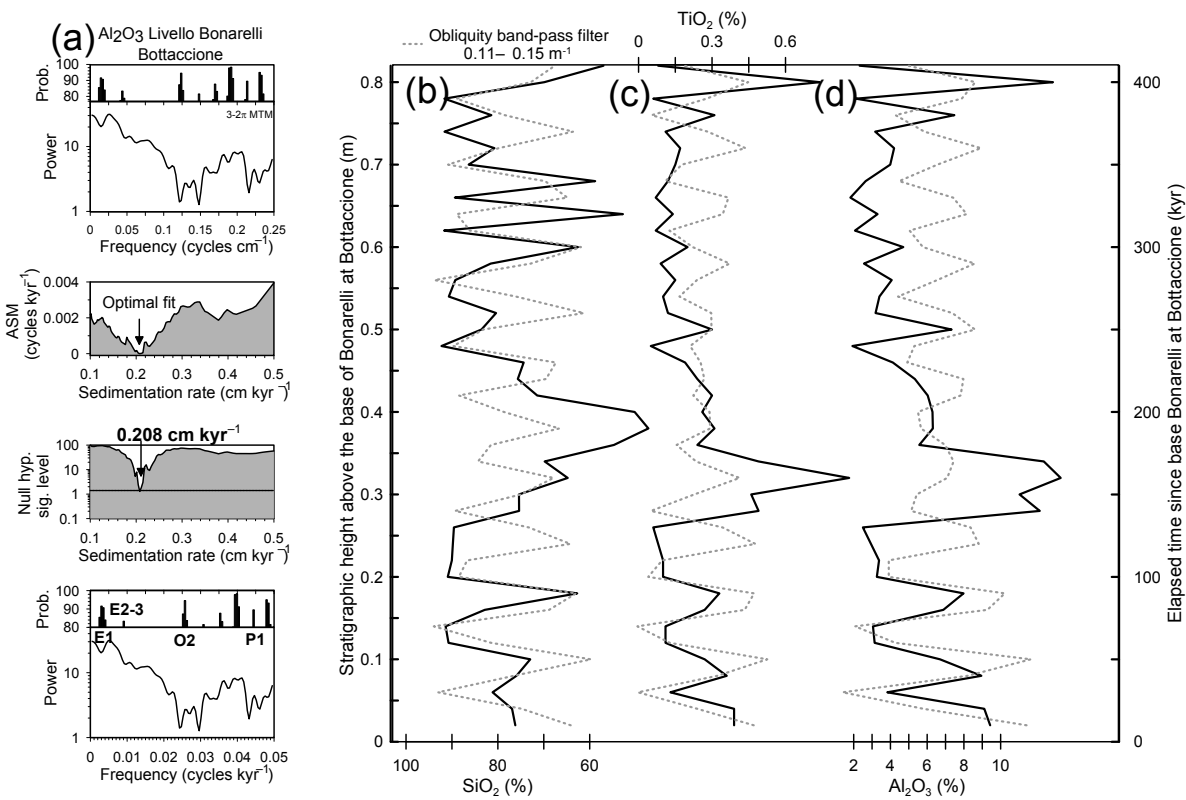

Figure 5. (a) Duration estimate of Livello Bonarelli at Bottaccione based on the average spectral misfit (ASM) method. (b-d) $\mathrm{SiO}_{2}$, TiO 2 and $\mathrm{Al}_{2} \mathrm{O}_{3}$ data show $\sim 8 \mathrm{~cm}$ thick cycles, interpreted as obliquity. The duration of the Livello Bonarelli at Bottaccione is estimated at $410 \mathrm{kyr}$.

despite variations in absolute values and amplitude amongst locations (Jarvis et al., 2006). The Cenomanian record presented here displays a higher degree of variability than a recently published bulk carbonate $\delta^{13} \mathrm{C}$ record from Furlo by Gambacorta et al. (2015). The high variability in $\delta^{13} \mathrm{C}$ values from 476 to $484 \mathrm{~m}$ coincides with a frequent occurrence of organic-matter-rich beds, which may have influenced $\delta^{13} \mathrm{C}$ values of early diagenetic cements. Although variability at the sampling scale $(3 \mathrm{~cm})$ may partially represent effects of diagenesis which could obscure short (precessional-scale) climatic signals, the longer-term trends compare well with coeval sections in the Umbria-Marche Basin (Sprovieri et al., 


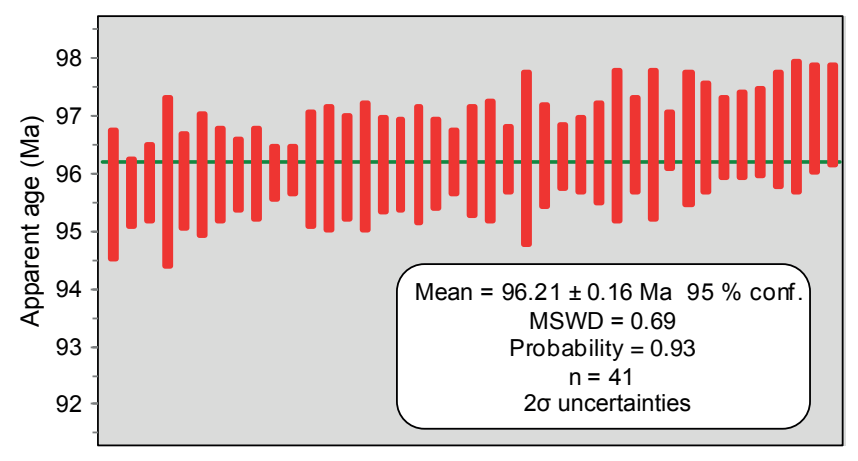

Figure 6. Summary of ${ }^{40} \mathrm{Ar} /{ }^{39} \mathrm{Ar}$ results.

2013; Stoll and Schrag, 2000) and the English Chalk records (Jarvis et al., 2006) (Fig. 9; see Sect. 4.5).

Whereas the stable isotope data reflect variations in temperature, salinity and the global carbon cycle, with superimposed regional and diagenetic effects, the other proxy data are closely related to lithological variations. These lithological variations reflect differing contributions of detrital input (indicated by magnetic susceptibility, $\mathrm{Al}_{2} \mathrm{O}_{3}, \mathrm{TiO}_{2}, \mathrm{SiO}_{2}$ ) and biological productivity of organic matter, carbonate and biogenic silica (reflected in the colour reflectance, LOI and $\mathrm{SiO}_{2}$ records). These variations show a local and direct response to orbitally forced variations in temperature, run-off and ventilation.

In this study, the base of the Turonian stage at Bottaccione is placed at $487.47 \mathrm{~m}$, just above the first occurrence of Quadrum gartneri at $487.25 \mathrm{~m}$ defining the base of the C11 zone (Sissingh, 1977), following Sprovieri et al. (2013) and Tsikos et al. (2004). Direct comparison of high-resolution $\delta^{13} \mathrm{C}_{\text {carb }}$ data from Pueblo (Caron et al., 2006) with $\delta^{13} \mathrm{C}_{\text {carb }}$ data from Contessa (Stoll and Schrag, 2000) allows for correlating $\delta^{13} \mathrm{C}_{\mathrm{carb}}$ maximum III in Pueblo with the $\delta^{13} \mathrm{C}_{\mathrm{carb}}$ maximum $85 \mathrm{~cm}$ above the Livello Bonarelli at $487.52 \mathrm{~cm}$, comparable with its location at Bottaccione. An alternative correlation places the $\mathrm{C} / \mathrm{T}$ boundary near a minimum in the $\delta^{13} \mathrm{C}_{\text {carb }}$ data from the Gubbio $\mathrm{S} 2$ core (Trabucho-Alexandre et al., 2011) of Tsikos et al. (2004), which corresponds to the minimum in $\delta^{13} \mathrm{C}_{\text {carb }}$ values at $488.22 \mathrm{~m}$ at Contessa (Stoll and Schrag, 2000), which is $75 \mathrm{~cm}$ above the C/T estimate adopted in this study. Consequently, $75 \mathrm{~cm}$ is taken as a conservative estimate of the stratigraphic uncertainty on the position of the $\mathrm{C} / \mathrm{T}$ boundary, i.e. $487.47 \pm 0.75 \mathrm{~m}$. With an average sedimentation rate of $11 \mathrm{~m} \mathrm{Myr}^{-1}$, this stratigraphic error margin translates into a temporal uncertainty of $\pm 68 \mathrm{kyr}$.

\subsection{Astronomical forcing and calibration}

\subsubsection{Astronomical phase relationships}

Throughout the Cenomanian interval of the Furlo section, black cherts occur in distinct bands, which are often underlain by a thin layer of black shale. As the organic-rich chert horizons are tabular and not nodular, they reflect a primary silica enrichment from radiolarian and/or diatom blooms. When present, black chert bands occur in groups with a regular spacing amongst them, likely reflecting a threshold response to extremes of the precessional cycle. Previous tuning attempts have placed black cherts either in eccentricity maxima (Mitchell et al., 2008; Voigt et al., 2006) or in eccentricity minima (Lanci et al., 2010). These interpretations entail distinctly different oceanographic regimes. During eccentricity maxima, the seasonal contrast on the Northern Hemisphere is periodically enhanced during high-amplitude precession minima, thereby intensifying monsoons, leading to an estuarine circulation in the Cretaceous North Atlantic with upwelling and increased productivity (Mitchell et al., 2008), potentially spurred by input of nutrients from volcanic activity (Trabucho-Alexandre et al., 2010). Alternatively, it has been suggested that eccentricity minima could cause decreased seasonality, leading to stagnation and reduced ventilation of bottom waters (Lanci et al., 2010; Herbert and Fischer, 1986), although eccentricity minima would not lower seasonality but rather avoid large seasonal extremes for a prolonged period of time. This reverse phase relationship is deduced from the remanent magnetization within carbonates at Furlo (Lanci et al., 2010), unfortunately excluding cherts and thereby obscuring the imprint of precession cycles on the sedimentary rhythms. Recently, by analysis of frequency modulation on the same dataset, Laurin et al. (2016) reevaluated the phase relationship and concluded that periods of increased black chert deposition coincided with eccentricity maxima.

We independently derived the phase relationship between eccentricity forcing and ocean-climate response from the degree of variability in the presented data. Intervals marked by maximal lithological difference represent periods of large precessional amplitude during eccentricity maxima. Radiolarian cherts coincide with maximal amplitude of carbon and oxygen isotope signals and with generally more negative values in those proxy records (Figs. 2 and 3). Negative $\delta^{18} \mathrm{O}$ values probably reflect warmer temperatures and increased influx of fresh water by increased monsoonal activity. Relatively low values of $\delta^{13} \mathrm{C}$ could be associated with stratification of the water column and reduced yearly integrated primary productivity (Sprovieri et al., 2013). Conversely, high $\delta^{13} \mathrm{C}$ values likely reflect good bottom-water ventilation during eccentricity minima, with a prolonged avoidance of seasonal extremes, allowing for more stable primary productivity over the annual cycle (Fig. 3). The increased accumulation of organic carbon on land due to more uniform annual precipitation during eccentricity minima may have amplified the rise in marine $\delta^{13} \mathrm{C}$, as suggested for Cenozoic intervals (Zachos et al., 2010). Figure 2 illustrates the phase relationship between intervals of black chert deposition and eccentricity based on proxy records from the Cenomanian Furlo section. An analogous phase relationship for the proxy records from the Bottaccione sections is inferred. There, 


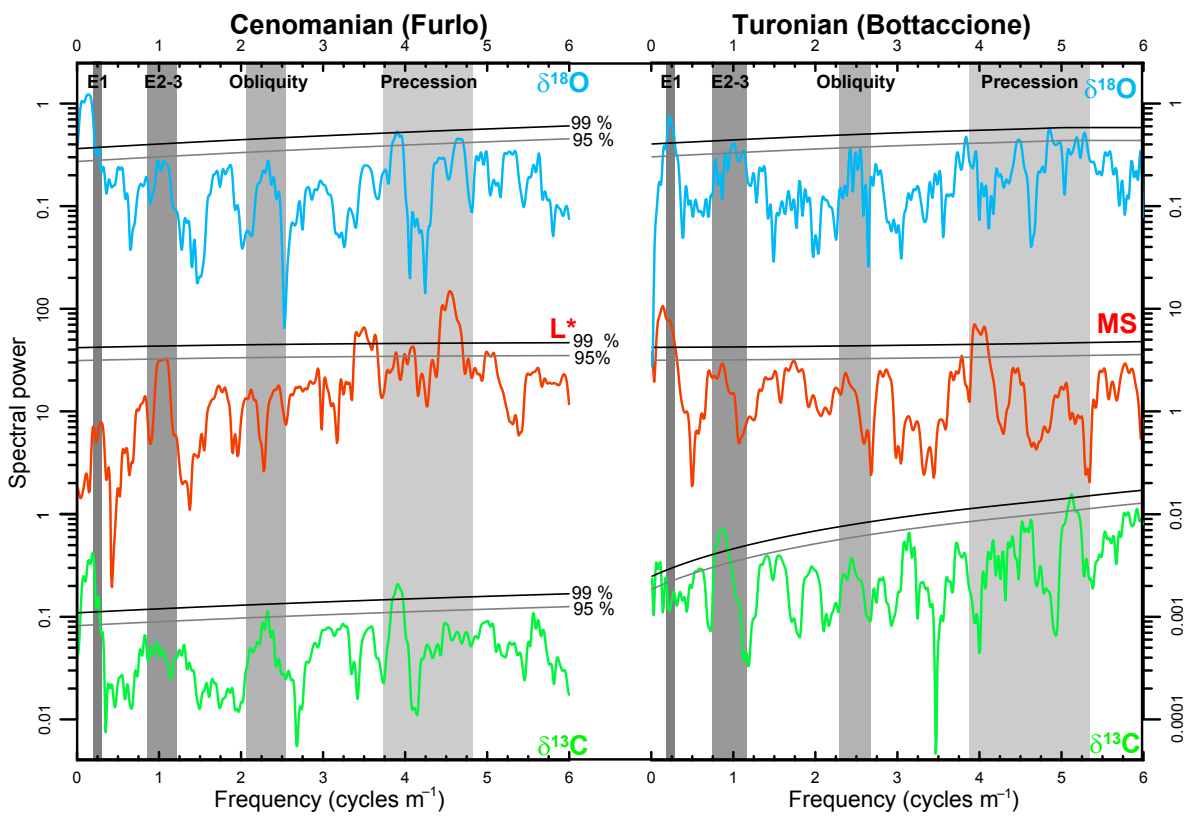

Figure 7. MTM/LOWSPEC spectra of proxy records. All proxy records show a strong imprint of eccentricity-modulated precession (E2-3: short eccentricity); $\delta^{13} \mathrm{C}$ from Furlo also displays a statistically significant (>95\% confidence level) imprint of obliquity.

black cherts are absent from the Turonian interval of the succession, but grey cherts occur rhythmically throughout. Increased variability and negative values of $\delta^{13} \mathrm{C}$ coincide with high variability in the magnetic susceptibility record in chertrich intervals, associated with eccentricity maxima.

\subsubsection{Calibration to 405 kyr eccentricity}

In this study, we distinguish minima and maxima of the $405 \mathrm{kyr}$ eccentricity cycle within the Scaglia Bianca and Scaglia Rossa by examining the band-pass filters of the physical property records. Near the end of the dataset in Furlo, below the Livello Bonarelli, and for the Turonian interval above the Livello Bonarelli, the pattern of individual limestonechert alternations is taken into account instead. The bandpass filters of the stable isotope data are presented to evaluate the cyclostratigraphic framework.

The present study provides a clear advancement over previous reports because (i) we use only the stable $405 \mathrm{kyr}$ periodicity of eccentricity in the La2011 solution (Laskar et al., 2011b) as tuning target, (ii) we present an independent estimate for the time span from the base of the Livello Bonarelli to the $\mathrm{C} / \mathrm{T}$ boundary, (iii) we use the astronomically calibrated age of $28.201 \mathrm{Ma}$ (Kuiper et al., 2008) for the Fish Canyon sanidine standard for ${ }^{40} \mathrm{Ar} /{ }^{39} \mathrm{Ar}$ dating, and (iv) we provide a new radioisotopic age for the mid-Cenomanian event. We discuss each of these aspects in the following paragraphs.

We correlate interpreted $405 \mathrm{kyr}$ eccentricity minima in the lithology and physical property data to $405 \mathrm{kyr}$ minima in the La2011 (nominal) eccentricity solution (Laskar et al., 2011a), obtained by band-pass filtering (300-625 kyr). Only the $405 \mathrm{kyr}$ component of eccentric is stable beyond $50 \mathrm{Ma}$, and it is the prime tuning target for the Cretaceous. The shorter obliquity and eccentricity-modulated precession terms can only be used for the development of floating timescales. Previous tuning efforts have used the $\sim 100 \mathrm{kyr}$ periodicity of eccentricity (Mitchell et al., 2008), extracted from the La2004 solution (Laskar et al., 2004), which is only considered reliable until $40 \mathrm{Ma}$.

Two $405 \mathrm{kyr}$ tuning options to astronomical solution La2011 remain if a C/T boundary age of $93.9 \pm 0.15 \mathrm{Ma}$ (Sageman et al., 2006; Meyers et al., 2012b) is considered, along with stratigraphic uncertainty in the studied sections $( \pm 0.068 \mathrm{Ma})$ and uncertainty in the astronomical solution. The uncertainty in the $405 \mathrm{kyr}$ component of the astronomical target curve was estimated at $\pm 78.5 \mathrm{kyr}$ by determining the maximal difference between the position of minima in the $405 \mathrm{kyr}$ band-pass filter outputs (300-625 kyr) of the La2010d, La2011 and La2011m2 solutions (Laskar et al., 2011a). The first $405 \mathrm{kyr}$ minimum in the Turonian at $489.1 \mathrm{~m}$ in Bottaccione corresponds to the $405 \mathrm{kyr}$ minimum in the astronomical solution at $93.5 \pm 0.15$ (tuning 1) or at $93.9 \pm 0.15 \mathrm{Ma}$ (tuning 2; Fig. 3).

Tuning options for the Cenomanian interval of this study depend on the duration of the Livello Bonarelli. The Livello Bonarelli in the Umbria-Marche Basin reflects the culmination of OAE 2, limited to the "second build-up" and "plateau" of the OAE $2 \delta^{13} \mathrm{C}$ excursion (Tsikos et al., 2004). The estimated duration in this study between the start of the $\delta^{13} \mathrm{C}$ excursion, below the Livello Bonarelli, and the 

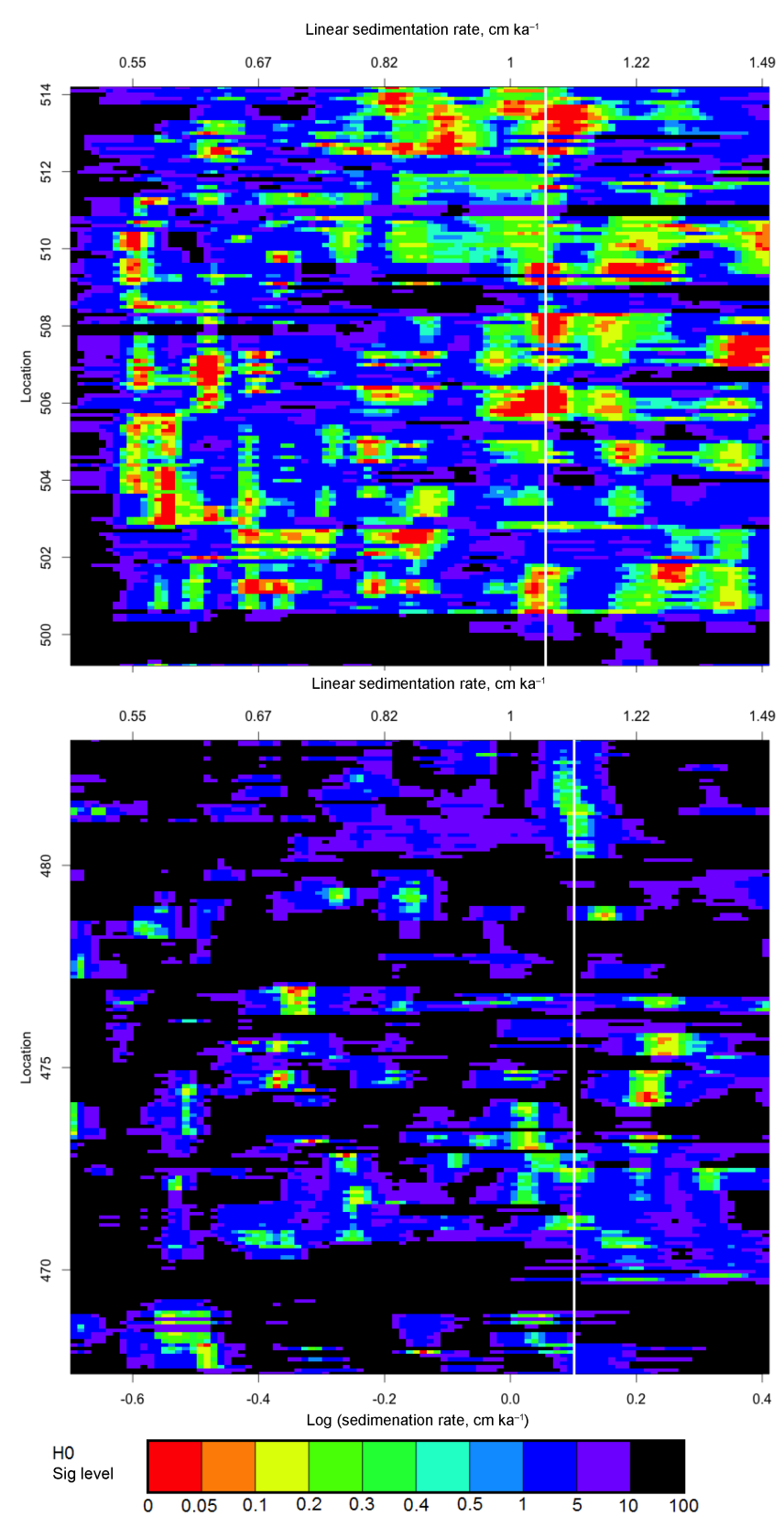

Figure 8. Evolutionary average spectral misfit (E-ASM) of the $\delta^{13} \mathrm{C}$ data from Furlo (bottom) and Bottaccione (top), with a $5 \mathrm{~m}$ window, $0.1 \mathrm{~m}$ steps and using those frequencies with $F$ test $>80 \%$. The white line suggests a stable sedimentation rate of $1.1 \mathrm{~cm} \mathrm{kyr}^{-1}$ in Furlo and $1.05 \mathrm{~cm} \mathrm{kyr}^{-1}$ in Bottaccione.

Cenomanian-Turonian boundary is $\sim 490 \mathrm{kyr}$. This duration is slightly longer than a previous estimate from the German Wunstorf core of 430-445 kyr for the OAE 2 isotope excursion (Takashima et al., 2009; Voigt et al., 2008), and slightly shorter than the duration of 520-560 kyr from the "first buildup" to the "end of plateau", determined by intercalibration between radioisotopic and astrochronologic timescales at the C/T Global Boundary Stratotype Section and Point (Sage- man et al., 2006; Meyers et al., 2012b). Similar duration estimates for this interval were obtained by reinterpreting the orbital influence at Demerara Rise and Tarfaya (500-550 kyr and 450-500 kyr, respectively; Meyers et al., 2012a) and in the Aristocrat-Angus-12-8 core in northern Colorado (516$613 \mathrm{kyr}$; Ma et al., 2014), as well as in the Iona core in Texas ( 540 kyr; Eldrett et al., 2015), albeit using slightly different correlations.

A potential complication arises from the sharp shifts in sedimentary facies at the base and the top of the Livello Bonarelli, which could be accompanied by hiatuses. A hiatus on the order of $20 \mathrm{kyr}$ at the base of the black shale has been suggested by Jenkyns et al. (2007). Such a hiatus would be relatively small compared to our tuning target, the $405 \mathrm{kyr}$ periodicity of eccentricity-modulated precession. In contrast, Gambacorta et al. (2015) suggest a large hiatus near the top of the Livello Bonarelli, based on correlation of the phases of OAE 2. This view is considered unlikely in this study, as there is no strong sedimentary evidence for such a hiatus, the duration of black shale deposition estimated here is in good agreement with other studies and the first occurrence of Quadrum gartneri is detected $58 \mathrm{~cm}$ above the base of the Scaglia Rossa.

The duration estimate for the Livello Bonarelli allows the extension of the astronomical tuning into the Cenomanian interval of this study. The base of the Livello Bonarelli corresponds to $94.19 \pm 0.15 \mathrm{Ma}$ (tuning 1 ) or $94.59 \pm 0.15 \mathrm{Ma}$ (tuning 2), i.e. the first short-eccentricity maximum after a 405 kyr minimum.

\subsubsection{Integration with radioisotopic ages}

The age for the base of the Livello Bonarelli of $94.19 \pm 0.15 \mathrm{Ma}$ (tuning 1 ) is similar to the previously reported age of 94.21 Ma (Mitchell et al., 2008). Nonetheless, Mitchell et al. (2008) used radioisotopic ages of Sageman et al. (2006), which were calculated using an age of $28.02 \pm 0.28 \mathrm{Ma}$ for the Fish Canyon sanidine standard (Renne et al., 1998), widely used in ${ }^{40} \mathrm{Ar} /{ }^{39} \mathrm{Ar}$ dating. In this study, ages are calculated with the recalibrated age of the Fish Canyon sanidine of $28.201 \pm 0.046 \mathrm{Ma}(\sigma)$ by Kuiper et al. (2008). Recalibration of the reported tuned age of 94.21 Ma (Mitchell et al., 2008) would correspond to an age of $94.81 \mathrm{Ma}$ after recalibration to the revised standard age of Kuiper et al. (2008), a difference of $1.5 \times 405 \mathrm{kyr}$ cycle.

Additional age control is provided by correlation of two Cenomanian ash beds from the Western Interior of the USA. Correlation to "Ash A" at the base of the boundary of the planktonic foraminifer biozones of Whiteinella archaeocretacea and Rotalipora cushmani (Sageman et al., 2006; Caron et al., 2006; Leckie, 1985) provides an independent age for this zonal boundary $7 \mathrm{~cm}$ below the base of the Bonarelli Level of $94.20 \pm 0.28 \mathrm{Ma}$. This age is in closer agreement with tuning $1(94.17 \pm 0.15 \mathrm{Ma})$ than with tuning $2(94.57 \pm 0.15 \mathrm{Ma})$. 


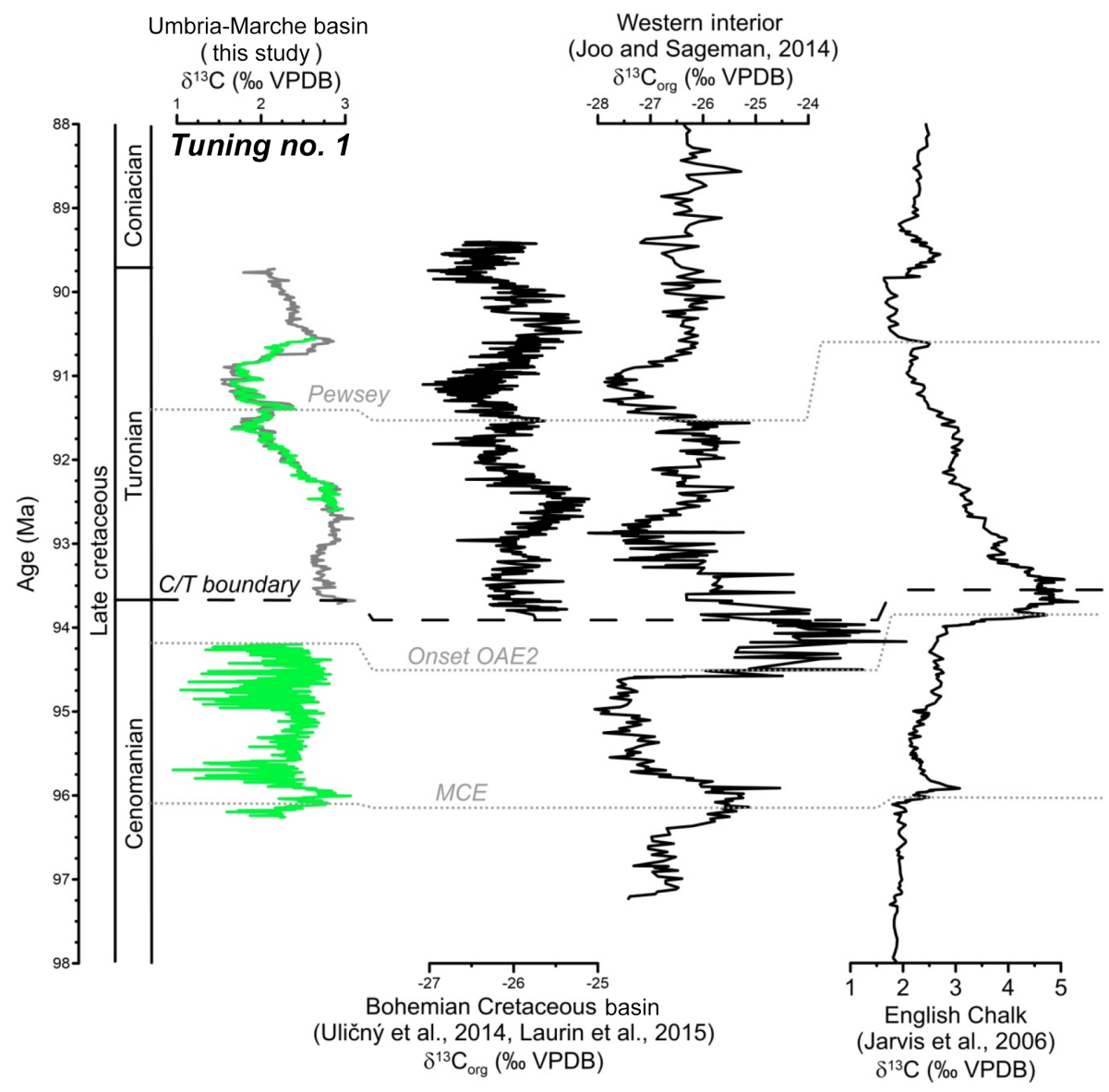

Figure 9. Global correlation of $\delta^{13} \mathrm{C}_{\mathrm{carb}}$ data of the Cenomanian-Turonian interval.

The MCE, characterized by a double positive peak in $\delta^{13} \mathrm{C}$ at Furlo (first maximum at $466.47 \mathrm{~m}$ ), offers another opportunity to test both tuning options. The ${ }^{40} \mathrm{Ar} /{ }^{39} \mathrm{Ar}$ isotope data were acquired from 41 single sanidine crystals in sample 91-O-03 of Obradovich (1993) (methods outlined in Sageman et al., 2014) and yield an age of $96.21 \pm 0.16 / 0.36$ ( $2 \sigma$ analytical and full uncertainty) for the Thatcher bentonite in the Conlinceras tarrantense zone at Pueblo, Colorado. This bentonite falls within the first peak of the MCE (Gale et al., 2008). In our tuning options, this level is either $96.09 \pm 0.15 \mathrm{Ma}$ (tuning 1) or $96.49 \pm 0.15 \mathrm{Ma}$ (tuning 2). Although tuning 2 is in better agreement with Eldrett et al. (2015), who report an age for the onset of the OAE 2 carbon isotope excursion of $94.64 \pm 0.12 \mathrm{Ma}$, the correlation to radioisotopic ages leads us to favour the first tuning option. Tuning 1 is in close agreement with the new ${ }^{40} \mathrm{Ar} /{ }^{39} \mathrm{Ar}$ age for the mid-Cenomanian event, the intercalibrated age for Ash A at the base of the Whiteinella archaeocretacea zone and the age of the $\mathrm{C} / \mathrm{T}$ boundary as determined by Meyers et al. (2012b). Nonetheless, the duration between radioisotopic age tie points is consistent with cyclostratigraphy (Fig. 2) and provides tuned ages for biostratigraphic events (Table 1).

\subsection{Long-term behaviour of the carbon cycle}

\subsubsection{Expression of long-term eccentricity forcing}

Superimposed on the hierarchical stacking patterns of lithologies in the studied succession, several features of the lithological and proxy records reveal the influence of longterm periodicities on local sedimentation and global climate. These observations include (i) the absence of cherts in an interval below the Livello Bonarelli; (ii) a strong expression of obliquity forcing during deposition of the Livello Bonarelli, contemporaneous with a sedimentary response to the $100 \mathrm{kyr}$ forcing of eccentricity; and (iii) a spacing of 2.0 between the mid-Cenomanian $\delta^{13} \mathrm{C}$ excursion and the onset of OAE 2 and of $2.4 \mathrm{Myr}$ between the onset of OAE 2 and a positive $\delta^{13} \mathrm{C}$ excursion in the mid-Turonian. These observations, in combination with a previously noted $\sim 1 \mathrm{Myr}$ cyclicity in $\delta^{13} \mathrm{C}$, reveal a pacing of climatic events by long-term eccentricity cycles.

Below the Livello Bonarelli, in the interval 483-485 m, black shales are conspicuously absent. This may partially be due to an increase in sedimentation rate, as indicated by a larger spacing between beds from $483.5 \mathrm{~m}$ upwards, but this pattern breaks the trend of an increasing number 
of black cherts and shales up-section, per metre as well as per interpreted $\sim 100 \mathrm{kyr}$ bundle. This may reflect the prolonged avoidance of seasonal extremes during long-term eccentricity minima of the $2.4 \mathrm{Myr}$ eccentricity cycle. The first $\sim 100 \mathrm{kyr}$ bundle of black cherts following this interval contains exceptionally thick, dark levels and corresponds to the beginning of the first $405 \mathrm{kyr}$ maximum after the $\sim 2.4 \mathrm{Myr}$ minimum. We associate the onset of OAE 2 with this $405 \mathrm{kyr}$ maximum.

Within the Livello Bonarelli, the imprint of $100 \mathrm{kyr}$ eccentricity cycles can be observed, comparable to the expression of OAE 2 in the Sicilian Calabianca section (Scopelliti et al., 2006) and in the German Wunstorf core (Voigt et al., 2008). Additionally, 10 obliquity-related cycles can be visually detected in the XRF-proxy data (Fig. 4b-e). Silica, delivered by radiolarian blooms, mirrors terrestrially derived components $\left(\mathrm{Al}_{2} \mathrm{O}_{3}\right.$ and $\left.\mathrm{TiO}_{2}\right)$ and may represent variations in seasonality and ventilation driven by obliquity during the deposition of the Livello Bonarelli.

Two pronounced $405 \mathrm{kyr}$ minima, likely within a $2.4 \mathrm{Myr}$ minimum, occur in the upper Cenomanian, the first of which could correspond (following tuning 1) to the interval lacking black shales at $483-485 \mathrm{~m}$, and the second occurring within the Livello Bonarelli. The occurrence of two $405 \mathrm{kyr}$ minima within a $2.4 \mathrm{Myr}$ minimum could explain the observed presence of the $\sim 100 \mathrm{kyr}$ cyclicity within the Livello Bonarelli, as well as the influence of obliquity, also detected during OAE 2 in several North Atlantic datasets (Meyers et al., 2012a). The Livello Bonarelli was previously suggested to coincide with a $2.4 \mathrm{Myr}$ eccentricity minimum, invoking stagnation as the forcing mechanism for anoxia (Mitchell et al., 2008). The relatively strong obliquity influence during the deposition of the Livello Bonarelli is consistent with this orbital configuration (Hilgen et al., 2003).

The new astrochronologies presented here allow for assessing the long-term behaviour of the carbon cycle during the $\mathrm{C} / \mathrm{T}$ transition. The onset of the MCE, the base of the Livello Bonarelli, and the middle of the negative $\delta^{13} \mathrm{C}$ excursion of the mid-Turonian are separated by 2.0 and $2.4 \mathrm{Myr}$, respectively. The $1.6 \mathrm{Myr}$ long negative excursion in the midTuronian is characterized by an intermittent double positive peak ("Pewsey events"; Jarvis et al., 2006; Fig. 9), similar to the MCE, starting at $91.7 \mathrm{Ma}$ (tuning 1) or $92.1 \mathrm{Ma}$ (tuning 2). These repetitive variations in $\delta^{13} \mathrm{C}$ are likely paced by the $\sim 2.4 \mathrm{Myr}$ eccentricity period. Following tuning 1 , a tentative comparison with the full-eccentricity solution La2011 (Fig. 2) reveals the occurrence of pronounced long-term minima in eccentricity before the mid-Cenomanian and midTuronian events. An influence of long-term (several Myr) cycles on $\delta^{13} \mathrm{C}$ has been previously identified in a late Cretaceous $\delta^{13} \mathrm{C}$ record from Bottaccione (Sprovieri et al., 2013). Recently, a $\sim 1 \mathrm{Myr}$ cycle was detected in the long-term behaviour of $\delta^{13} \mathrm{C}$, particularly in the Turonian record from the Bohemian Cretaceous Basin (Fig. 9), and attributed to the $\sim 1.2$ Myr cycle in amplitude modulation of Earth's ax- ial obliquity (Laurin et al., 2015). Although a $\sim 1$ Myr periodicity cannot be identified in our data, an influence of obliquity forcing is observed in the Cenomanian part of the record. Sharp positive excursions paced by $\sim 2.4 \mathrm{Myr}$ eccentricity modulation may have occurred superimposed on gradual $\sim 1 \mathrm{Myr}$ cycles in $\delta^{13} \mathrm{C}$ variation.

The Cenomanian $\delta^{13} \mathrm{C}$ curve is more strongly paced by the $405 \mathrm{kyr}$ cycle than the Turonian $\delta^{13} \mathrm{C}$ curve. Such a change was previously observed for the end of the Albian and interpreted to reflect a change to more stable ocean circulation patterns (Giorgioni et al., 2012). For the CenomanianTuronian, the carbon cycle may have become more stable as $\mathrm{CO}_{2}$ was drawn down by organic matter deposition and volcanic activity decreased.

\subsubsection{Relation with volcanism}

The increasing recurrence of black cherts through the Cenomanian interval indicates that the western Tethys was progressively more prone to the development of anoxia due to a long-term trend of ongoing warming and increased volcanism. Trace-element studies point to volcanic activity at the Caribbean Large Igneous Province as the supplier of nutrients and sulfate to a low-sulfate ocean, with a major pulse $\sim 500$ kyr before OAE 2 (Snow et al., 2005; Turgeon and Creaser, 2008; Adams et al., 2010; Jenkyns et al., 2007). Volcanism is thus ultimately responsible for $\mathrm{OAE} 2$, but the exact timing of the onset of OAE 2 seems to be linked to a specific sequence of astronomical variations superimposed on this trend. The increased variability in seasonality, after the prolonged avoidance of seasonal extremes, gave rise to an intensification of the hydrological cycle, weathering, and more vigorous ocean circulation, which is in agreement with several $\mathrm{Nd}$ isotope records (Martin et al., 2012; Zheng et al., 2013) and Os isotope records (Du Vivier et al., 2014). Deep waters at Demerara Rise were replaced by bottom waters sourced from the Tethys and North Atlantic (Martin et al., 2012). Trabucho-Alexandre et al. (2010) suggest that the OAE 2 interval may have been characterized by an intense estuarine circulation with upwelling in the protoNorth Atlantic. This is consistent with the phase relationship inferred from our data: i.e. black chert and shale deposition coincident with seasonality extremes during $405 \mathrm{kyr}$ eccentricity maxima. Previously, Mitchell et al. (2008) placed OAE 2 within the $\sim 2.4 \mathrm{Myr}$ minimum itself and suggested that the lack of strong insolation variability, associated with such a minimum, prevented the system from changing states and hindered limestone deposition. However, our chronology advocates intensified circulation and upwelling, delivering nutrients from volcanism and weathering to the western Tethys and the North Atlantic, and triggering prolonged and widespread anoxia. In conclusion, the $6 \mathrm{Myr}$ long astronomically tuned timescale across OAE 2 presented in this study allows for the evaluation and combination of two leading hypotheses about OAE 2 forcing mechanisms. 


\section{Data availability}

The colour reflectance, magnetic susceptibility, and stable isotope data are available on Pangaea: https://doi.pangaea.de/ 10.1594/PANGAEA.864716.

\section{The Supplement related to this article is available online at doi:10.5194/cp-12-1995-2016-supplement.}

Acknowledgements. Special thanks go to the association "Le montagne di San Francesco" for logistic support in the field, as well as the inhabitants of Coldigioco. We would like to thank Michele Iavarone for isotope analyses; the editor, Yves Godderis, for handling the manuscript; Jiří Laurin and two anonymous reviewers for their feedback; and Stephen Meyers, Nicolas Thibault, Ian Jarvis, André Bornemann and Simone Galeotti for comments on a previous version of the manuscript. Sietske J. Batenburg thanks the European Community funded GTSnext project (grant agreement 215458), the European Science Foundation activity "EARTHTIME - The European Contribution" (exchange grant 3818) and the German Research Foundation (DFG VO 687/14-1, IODP/ODP SSP 527/32). Philippe Claeys acknowledges the support of the Hercules Foundation for the upgrade of the VUB stable isotope laboratory.

Edited by: Y. Godderis

Reviewed by: two anonymous referees

\section{References}

Adams, D., Hurtgen, M., and Sageman, B.: Volcanic triggering of a biogeochemical cascade during Oceanic Anoxic Event 2, Nat. Geosci., 3, 201-204, 2010.

Alvarez, W., Montanari, A., and Shimabukuro, D.: Ex Libro Lapidum Historia Mundi: Reading History Written in Rocks, in: Evolution: A Big History Perspective, edited by: Grinin, L. E., Korotayev, A. V., and Rodrigue, B. H., Uchitel Publishing House, Volgograd, 145-157, 2011.

Beaudouin, B., M'Ban, E. P., Montanari, A., and Pinault, M.: Lithostratigraphie haute résolution $(<20 \mathrm{ka})$ dans le Cénomanien du bassin d'Ombrie-Marches (Italie), C. R. Acad. Sci., 323, 689696, 1996.

Berger, A., Loutre, M. F., and Laskar, J.: Stability of the Astronomical Frequencies Over the Earth's History for Paleoclimate Studies, Science, 255, 560-566, 1992.

Caron, M., Dall'Agnolo, S., Accarie, H., Barrera, E., Kauffman, E., Amédro, F., and Robaszynski, F.: High-resolution stratigraphy of the Cenomanian-Turonian boundary interval at Pueblo (USA) and wadi Bahloul (Tunisia): stable isotope and bio-events correlation, Geobios, 39, 171-200, 2006.

Cleveland, W. S.: Robust Locally Weighted Regression and Smoothing Scatterplots, J. Am. Stat. Assoc., 74, 829-836, 1979.

Coccioni, R.: The Cretaceous of the Umbria-Marche Apennines (Central Italy). Jost Wiedmann Symposium "Cretaceous Stratigraphy, Paleobiology and Paleobiogeography", Tübingen, 7-10 March 1996, 129-136, 1996. de Boer, P. L.: Cyclicity and the Storage of Organic Matter in Middle Cretaceous Pelagic Sediments, in: Cyclic and Event Stratification, edited by: Einsele, G. and Seilacher, A., Springer Berlin Heidelberg, Berlin, Heidelberg, 456-475, 1982.

de Boer, P. L.: Aspects of middle cretaceous pelagic sedimentation in Southern Europe: production and storage of organic matter, stable isotopes, and astronomical influences, Geol. Ultra., 31, 1112, 1983.

Du Vivier, A., Selby, D., Sageman, B., Jarvis, I., Gröcke, D., and Voigt, S.: Marine ${ }^{187} \mathrm{Os} /{ }^{188} \mathrm{Os}$ isotope stratigraphy reveals the interaction of volcanism and ocean circulation during Oceanic Anoxic Event 2, Earth Planet. Sci. Lett., 389, 23-33, 2014.

Eldrett, J. S., Ma, C., Bergman, S. C., Lutz, B., Gregory, F. J., Dodsworth, P., Phipps, M., Hardas, P., Minisini, D., Ozkan, A., Ramezani, J., Bowring, S. A., Kamo, S. L., Ferguson, K., Macaulay, C., and Kelly, A. E.: An astronomically calibrated stratigraphy of the Cenomanian, Turonian and earliest Coniacian from the Cretaceous Western Interior Seaway, USA: Implications for global chronostratigraphy, Cret. Res., 56, 316-344, 2015.

Gale, A., Voigt, S., Sageman, B., and Kennedy, W.: Eustatic sealevel record for the Cenomanian (Late Cretaceous) - extension to the Western Interior Basin, USA, Geology, 36, 859-862, 2008.

Gambacorta, G., Jenkyns, H. C., Russo, F., Tsikos, H., Wilson, P. A., Faucher, G., and Erba, E.: Carbon- and oxygen-isotope records of mid-Cretaceous Tethyan pelagic sequences from the UmbriaMarche and Belluno Basins (Italy), Newsletters on Stratigraphy, 48, 299-323, 2015

Giorgioni, M., Weissert, H., Bernasconi, S. M., Hochuli, P. A., Coccioni, R., and Keller, C. E.: Orbital control on carbon cycle and oceanography in the mid-Cretaceous greenhouse, Paleoceanography, 27, PA1024, doi:10.1029/2011PA002163, 2012.

Herbert, T. D. and Fischer, A. G.: Milankovitch climatic origin of mid-Cretaceous black shale rhythms in central Italy, Nature, 321, 739-743, 1986.

Hilgen, F., Aziz, H. A., Krijgsman, W., Raffi, I., and Turco, E.: Integrated stratigraphy and astronomical tuning of the Serravallian and lower Tortonian at Monte dei Corvi (MiddleUpper Miocene, northern Italy), Palaeogeogr. Palaeoclimatol. Palaeoecol., 199, 229-264, 2003.

Jarvis, I., Gale, A., Jenkyns, H., and Pearce, M.: Secular variation in Late Cretaceous carbon isotopes: a new $\delta^{13} \mathrm{C}$ carbonate reference curve for the Cenomanian-Campanian (99.6-70.6 Ma), Geol. Mag., 143, 561-608, 2006.

Jenkyns, H. C., Gale, A. S., and Corfield, R. M.: Carbon- and oxygen-isotope stratigraphy of the English Chalk and Italian Scaglia and its palaeoclimatic significance, Geol. Mag., 131, 134, 1994

Jenkyns, H. C., Matthews, A., Tsikos, H., and Erel, Y.: Nitrate reduction, sulfate reduction, and sedimentary iron isotope evolution during the Cenomanian-Turonian oceanic anoxic event, $\mathrm{Pa}-$ leoceanography, 22, PA3208, doi:10.1029/2006PA001355, 2007.

Kuiper, K., Deino, A., Hilgen, F., Krijgsman, W., Renne, P., and Wijbrans, J.: Synchronizing rock clocks of Earth history, Science, 320, 500-504, 2008.

Kuroda, J., Ogawa, N. O., Tanimizu, M., Coffin, M. F., Tokuyama, H., Kitazato, H., and Ohkouchi, N.: Contemporaneous massive subaerial volcanism and late cretaceous Oceanic Anoxic Event 2, Earth Planet. Sci. Lett., 256, 211-223, 2007. 
Lanci, L., Muttoni, G., and Erba, E.: Astronomical tuning of the Cenomanian Scaglia Bianca Formation at Furlo, Italy, Earth Planet. Sci. Lett., 292, 231-237, 2010.

Laskar, J., Robutel, P., Joutel, F., Gastineau, M., Correia, A., and Levrard, B.: A long-term numerical solution for the insolation quantities of the Earth, Astron. Astrophys., 428, 261-285, 2004.

Laskar, J., Fienga, A., Gastineau, M., and Manche, H.: La2010: a new orbital solution for the long-term motion of the Earth, Astron. Astrophys., 532, A89, 2011a.

Laskar, J., Gastineau, M., Delisle, J., Farrés, A., and Fienga, A.: Strong chaos induced by close encounters with Ceres and Vesta, Astron. Astrophys., 532, L4, 2011b.

Laurin, J., Meyers, S., Uličný, D., Jarvis, I., and Sageman, B.: Axial obliquity control on the greenhouse carbon budget through middle- to high-latitude reservoirs, Paleoceanography, 30, 133149, 2015.

Laurin, J., Meyers, S. R., Galeotti, S., and Lanci, L.: Frequency modulation reveals the phasing of orbital eccentricity during Cretaceous Oceanic Anoxic Event II and the Eocene hyperthermals, Earth Planet. Sci. Lett., 442, 143-156, 2016.

Leckie, R. M.: Foraminifera of the Cenomanian-Turonian boundary interval, Greenhorn Formation, Rock Canyon Anticline, Pueblo, Colorado, in: Fine-grained deposits and biofacies of the Cretaceous Western Interior Seaway: Evidence of cyclic sedimentary processess: SEPM Field Trip Guidebook No. 4, edited by: Pratt, L., Kauffman, E., and Zelt, F., 139-155, 1985.

Ma, C., Meyers, S. R., Sageman, B. B., Singer, B. S., and Jicha, B. R.: Testing the astronomical time scale for oceanic anoxic event 2, and its extension into Cenomanian strata of the Western Interior Basin (USA), Geol. Soc. Am. Bull., 126, 974-989, 2014.

Martin, E. E., MacLeod, K. G., Berrocoso, A. J., and Bourbon, E.: Water mass circulation on Demerara Rise during the Late Cretaceous based on Nd isotopes, Earth Planet. Sci. Lett., 327, 111120, doi:10.1016/j.epsl.2012.01.037, 2012.

Meyers, S. and Sageman, B.: Quantification of deep-time orbital forcing by average spectral misfit, Am. J. Sci., 307, 773-792, 2007.

Meyers, S., Sageman, B., and Arthur, M.: Obliquity forcing of organic matter accumulation during Oceanic Anoxic Event 2, Paleoceanography, 27, PA3212, doi:10.1029/2012PA002286, 2012a.

Meyers, S., Siewert, S., Singer, B., Sageman, B., Condon, D., Obradovich, J., Jicha, B., and Sawyer, D.: Intercalibration of radioisotopic and astrochronologic time scales for the Cenomanian-Turonian boundary interval, Western Interior Basin, USA, Geology, 40, 7-10, 2012b.

Meyers, S. R.: Seeing red in cyclic stratigraphy: Spectral noise estimation for astrochronology, Paleoceanography, 27, PA3228, doi:10.1029/2012PA002307, 2012.

Meyers, S. R.: Astrochron: An R Package for Astrochronology, http://cran.r-project.org/package=astrochron (last access: 26 September 2016), 2014.

Min, K., Mundil, R., Renne, P. R., and Ludwig, K. R.: A test for systematic errors in 40Ar/39Ar geochronology through comparison with $\mathrm{U} / \mathrm{Pb}$ analysis of a 1.1-Ga rhyolite, Geochim. Cosmochim. Acta, 64, 73-98, 2000.

Mitchell, R., Bice, D., Montanari, A., Cleaveland, L., Christianson, K., Coccioni, R., and Hinnov, L.: Oceanic anoxic cycles? Orbital prelude to the Bonarelli Level (OAE 2), Earth Planet. Sci. Lett., 267, 1-16, 2008.
Montanari, A., Chan, L., and Alvarez, W.: Synsedimentary Tectonics in the Late Cretaceous Early Tertiary Pelagic Basin of the Northern Apennines, Italy, in: Controls on Carbonate Platform and Basin Development, edited by: Crevello, P. D., Wilson, J. L., Sarg, J. F., and Read, J. F., The Society of Economic Paleontologists and Mineralogists, Spec. Publ., 44, 379-399, 1989.

Obradovich, J.: A Cretaceous time scale, in: Evolution of the Western Interior Basin, edited by: Caldzell, W. G. E., and Kauffman, E., Geological Association of Canada, 379-396, 1993.

Paillard, D., Labeyrie, L., and Yiou, P.: Macintosh program performs time-series analysis, Eos, Transactions American Geophysical Union, 77, p. 379, 1996.

Reimold, W. U., Koeberl, C., and Bishop, J.: Roter Kamm impact crater, Namibia: Geochemistry of basement rocks and breccias, Geochim. Cosmochim. Acta, 58, 2689-2710, 1994.

Renne, P., Deino, A., Hilgen, F., Kuiper, K., Mark, D., Mitchell, W., Morgan, L., Mundil, R., and Smit, J.: Time Scales of Critical Events Around the Cretaceous-Paleogene Boundary, Science, 339, 684-687, doi:10.1126/science.1230492, 2013.

Renne, P. R., Swisher, C. C., Deino, A. L., Karner, D. B., Owens, T. L., and DePaolo, D. J.: Intercalibration of standards, absolute ages and uncertainties in 40Ar/39Ar dating, Chem. Geol., 145, 117-152, 1998.

Ruckstuhl, A. F., Jacobson, M. P., Field, R. W., and Dodd, J. A.: Baseline subtraction using robust local regression estimation, J. Quant. Spectrosc. Rad. Transf., 68, 179-193, 2001.

Sageman, B., Meyers, S., and Arthur, M.: Orbital time scale and new C-isotope record for Cenomanian-Turonian boundary stratotype, Geology, 34, 125-128, 2006.

Sageman, B. B., Singer, B. S., Meyers, S. R., Siewert, S. E., Walaszczyk, I., Condon, D. J., Jicha, B. R., Obradovich, J. D., and Sawyer, D. A.: Integrating 40Ar/39Ar, U-Pb, and astronomical clocks in the Cretaceous Niobrara Formation, Western Interior Basin, USA, Geol. Soc. Am. Bull., 126, 956-973, 2014.

Schwarzacher, W.: Cyclostratigraphy of the Cenomanian in the Gubbio district, Italy: a field study, in: Orbital forcing and cyclic sequences, edited by: De Boer, P. L. and Smith, D. G., Blackwell Publishing Ltd., Oxford, 87-97, 1994.

Scopelliti, G., Bellanca, A., Neri, R., Baudin, F., and Coccioni, R.: Comparative high-resolution chemostratigraphy of the Bonarelli Level from the reference Bottaccione section (Umbria-Marche Apennines) and from an equivalent section in NW Sicily: Consistent and contrasting responses to the OAE 2, Chem. Geol., 228, 266-285, 2006.

Sinton, C. and Duncan, R.: Potential links between ocean plateau volcanism and global ocean anoxia at the Cenomanian-Turonian boundary, Econ. Geol., 92, 836-842, 1997.

Sissingh, W.: Biostratigraphy of Cretaceous calcareous nannoplankton, Geologie en mijnbouw, 56, 37-65, 1977.

Snow, L., Duncan, R., and Bralower, T.: Trace element abundances in the Rock Canyon Anticline, Pueblo, Colorado, marine sedimentary section and their relationship to Caribbean plateau construction and oxygen anoxic event 2, Paleoceanography, 20, PA3005, doi:10.1029/2004PA001093, 2005.

Sprovieri, M., Sabatino, N., Pelosi, N., Batenburg, S. J., Coccioni, R., Iavarone, M., and Mazzola, S.: Late Cretaceous orbitallypaced carbon isotope stratigraphy from the Bottaccione Gorge (Italy), Palaeogeogr. Palaeoclimatol. Palaeoecol., 379-380, 8194, 2013. 
Stoll, H. and Schrag, D.: High-resolution stable isotope records from the Upper Cretaceous rocks of Italy and Spain: Glacial episodes in a greenhouse planet?, Geol. Soc. Am. Bull., 112, 308-319, 2000.

Takashima, R., Nishi, H., Hayashi, K., Okada, H., Kawahata, H., Yamanaka, T., Fernando, A. G., and Mampuku, M.: Litho-, bioand chemostratigraphy across the Cenomanian-Turonian boundary (OAE 2) in the Vocontian Basin of southeastern France, Palaeogeogr. Palaeoclimatol. Palaeoecol., 273, 61-74, 2009.

Thomson, D. J.: Spectrum Estimation and Harmonic-Analysis, Proc. IEEE, 70, 1055-1096, 1982.

Trabucho-Alexandre, J., Tuenter, E., Henstra, G., van der Zwan, K., van de Wal, R., Dijkstra, H., and de Boer, P.: The mid-Cretaceous North Atlantic nutrient trap: Black shales and OAEs, Paleoceanography, 25, PA4201, doi:10.1029/2010pa001925, 2010.

Trabucho-Alexandre, J., Negri, A., and de Boer, P. L.: Early Turonian pelagic sedimentation at Moria (Umbria-Marche, Italy): Primary and diagenetic controls on lithological oscillations, Palaeogeogr. Palaeoclimatol. Palaeoecol., 311, 200-214, 2011.

Tsikos, H., Jenkyns, H. C., Walsworth-Bell, B., Petrizzo, M. R., Forster, A., Kolonic, S., Erba, E., Silva, I. P., Baas, M., Wagner, T., and Damste, J. S. S.: Carbon-isotope stratigraphy recorded by the Cenomanian-Turonian Oceanic Anoxic Event: correlation and implications based on three key localities, J. Geol. Soc., 161, 711-719, 2004.
Turgeon, S. and Creaser, R.: Cretaceous oceanic anoxic event 2 triggered by a massive magmatic episode, Nature, 454, 323-326, 2008.

Voigt, S., Gale, A., and Voigt, T.: Sea-level change, carbon cycling and palaeoclimate during the Late Cenomanian of northwest Europe; an integrated palaeoenvironmental analysis, Cret. Res., 27, 836-858, 2006.

Voigt, S., Erbacher, J., Mutterlose, J., Weiss, W., Westerhold, T., Wiese, F., Wilmsen, M., and Wonik, T.: The Cenomanian Turonian of the Wunstorf section (North Germany): global stratigraphic reference section and new orbital time scale for Oceanic Anoxic Event 2, Newsletters on Stratigraphy, 43, 65-89, 2008.

Zachos, J. C., McCarren, H., Murphy, B., Röhl, U., and Westerhold, T.: Tempo and scale of late Paleocene and early Eocene carbon isotope cycles: Implications for the origin of hyperthermals, Earth Planet. Sci. Lett., 299, 242-249, 2010.

Zheng, X.-Y., Jenkyns, H., Gale, A., Ward, D., and Henderson, G.: Changing ocean circulation and hydrothermal inputs during Ocean Anoxic Event 2 (Cenomanian-Turonian): evidence from Nd-isotopes in the European shelf sea, Earth Planet. Sci. Lett., 375, 338-348, 2013. 